\title{
Treatment of orbital venous malformation type 2 with a bleomycin injection
}

\author{
Michael Stuart Howells 다, Rohit Sharma
}

Ophthalmology, University Hospitals of Derby and Burton NHS Foundation Trust, Derby, UK

Correspondence to Dr Michael Stuart Howells; michael.howells1@nhs.net

Accepted 21 January 2021

\section{DESCRIPTION}

Orbital venous malformation type 2, previously called orbital varices, ${ }^{1}$ are dilatations of the veins draining the eye causing proptosis due to engorgement of the vessels which can lead to haemorrhage, thrombosis and orbital nerve compression. ${ }^{2}$ While symptoms are usually mild and treatment is usually conservative, they can cause the patient some discomfort, pain and blurring of vision, surgical options include sclerotherapy and a transpalpebral approach to ligate the pedicle of the malformation. Ultimately, treatment should be guided by the severity of symptoms and functional disturbances. ${ }^{1}$ In this case, we have followed up a 43-year-old man over 1 year, who initially presented in 2019 with pressure behind the eye and swelling, especially if he bends over, and a blurring of vision (figure 1). He is otherwise fit and well. He opted for a bleomycin injection as he found his symptoms uncomfortable. Bleomycin is used as a sclerosing agent which provokes local intimal inflammation which leads to thrombosis resulting in a reduction in size of the malformation. ${ }^{3}$ Bleomycin injections have been shown to reduce proptosis, pain and swelling in patients, as well as a reduction in the venous volume by 70\%-75\% measured by CT scan. ${ }^{4}$ Following the injection, the patient is pleased with the results and reported improvement of symptoms, although not complete relief, and no adverse effects (figure 2). We plan to continue following up the patient to see whether there are any long-term adverse effects

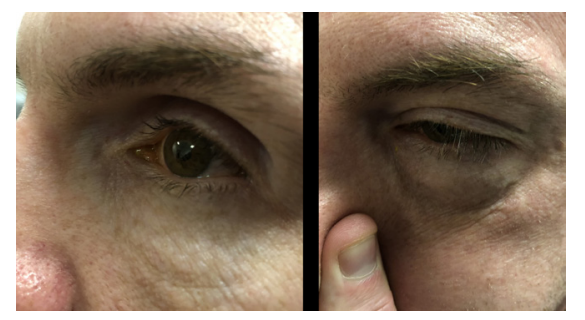

Figure 1 The patient at rest (left) and performing the Valsalva manoeuvre (right)—showing proptosis of the left eye before treatment.

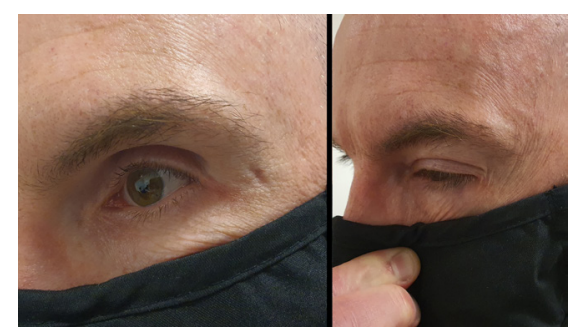

Figure 2 The patient at rest (left) and performing the Valsalva manoeuvre (right) after treatment.

\section{Patient's perspective}

Since I had the injection, the swelling I get from bending over around the eye has been reduced significantly. The eye still swells when I perform a Valsalva manoeuvre but this is not something I do often. I have had no side effects from the injection and although it has not completely resolved my condition, I feel it has worked well.

\section{Learning points}

- 1.Orbital venous malformation type 2 are relatively rare and treatment is usually conservative.

- Bleomycin injections are well tolerated with few systemic complications.

- Risks of sclerotherapy include orbital compartment syndrome due to swelling and tissue necrosis. ${ }^{1}$

from the treatment and whether or not there is a need for repeated injections.

Acknowledgements Mr S Chawdhary (University Hospitals of Derby and Burton NHS Foundation Trust), Mr R Samanth (University Hospitals of Leicester NHS Trust).

Contributors RS initially saw the case in clinic and proposed the case report to MSH who initially wrote it up. The patient was followed up by RS in clinic following treatment and the report was again written up by MSH with guidance from RS.

Funding The authors have not declared a specific grant for this research from any funding agency in the public, commercial or not-for-profit sectors.

Competing interests None declared.

Patient consent for publication Obtained.

Provenance and peer review Not commissioned; externally peer reviewed.

ORCID iD

Michael Stuart Howells http://orcid.org/0000-0003-3625-1277

\section{REFERENCES}

1 Colletti G, Biglioli F, Poli T, et al. Vascular malformations of the orbit (lymphatic, venous, arteriovenous): diagnosis, management and results. J Craniomaxillofac Surg 2019;47:726-40.

2 Islam N, Mireskandari K, Rose GE. Orbital varices and orbital wall defects. Br J Ophthalmol 2004;88:833-4.

3 Chen W-L, Yang Z-H, Bai Z-B, et al. A pilot study on combination compartmentalisation and sclerotherapy for the treatment of massive venous malformations of the face and neck. J Plast Reconstr Aesthet Surg 2008;61:1486-92.

4 Yue H, Qian J, Elner VM, et al. Treatment of orbital vascular malformations with intralesional injection of pingyangmycin. $\mathrm{Br} \mathrm{J}$ Ophthalmol 2013;97:739-45. 
Copyright 2021 BMJ Publishing Group. All rights reserved. For permission to reuse any of this content visit https://www.bmj.com/company/products-services/rights-and-licensing/permissions/

BMJ Case Report Fellows may re-use this article for personal use and teaching without any further permission.

Become a Fellow of BMJ Case Reports today and you can:

- Submit as many cases as you like

Enjoy fast sympathetic peer review and rapid publication of accepted articles

Access all the published articles

Re-use any of the published material for personal use and teaching without further permission

Customer Service

If you have any further queries about your subscription, please contact our customer services team on +44 (0) 2071111105 or via email at support@bmj.com.

Visit casereports.bmj.com for more articles like this and to become a Fellow 